\title{
As teorias da secularização e da individualização em análise comparada
}

\author{
Jorge Botelho Moniz*
}

\section{Resumo}

Muito se tem escrito sobre a secularização, mas poucas têm sido as investigações profundas a respeito das suas camadas internas e acerca das alternativas mais sólidas e sistemáticas que lhe seguiram. Ao nosso ver, isto refletiu-se em dificuldades de compreensão interpretativa e de aprofundamento teórico-analítico que são necessárioas e possíveis de ultrapassar. Para cumprir tal desiderato, escolhemos um desenho de investigação que engloba as estratégias da descrição densa e do método comparativo e dividimos o trabalho em duas partes essenciais. Em primeiro lugar, analisamos os principais substratos da secularização, nomeadamente a diferenciação funcional, a racionalização, a societalização, a segurança existencial e a diversidade, igualitarismo e individualismo. Em segundo lugar, introduzimos aquela que, para o estado da arte, é uma das principais e mais desafiantes alternativas às teorias da secularização - a individualização -, examinando-a à luz dos seus pressupostos fundamentais. No final do trabalho, para efeitos de maior sistematização, oferecemos um quadro de análise com a comparação dos principais axiomas das duas teorias.

Palavras-chave: Secularização. Individualização. Método comparativo.

\section{The theories of secularization and individualization in comparative perspective}

\begin{abstract}
Much has been written on secularization, but there have been few profound investigations on its internal layers and on its the most solid and systematic alternatives that followed it. In our view, this has had two consequences: constraints of interpretative understanding and of analytical-theoretical deepening that must and can be overcome.

\footnotetext{
Universidade Nova de Lisboa, Universidade Federal de Santa Catarina e Observatório Político. Doutorando em em Ciência Política e mestre em Direito pela Universidade Nova de Lisboa. Bolseiro da FCT - Fundação para a Ciência e Tecnologia (Portugal) na Universidade Federal de Santa Catarina no Programa de Pós-Graduação em Sociologia Política. Investigador associado do Observatório Político.Professor convidado em SciencesPo (Poitiers, França).
} 
To achieve this goal, we have chosen a research design that encompasses the strategy of thick description as well as the comparative method and we divided the paper in two basic parts. First, we analyse the main substrates of secularization, namely functional differentiation, rationalization, societalization, existential security and diversity, egalitarianism and individualism. Secondly, we introduce one of the most important and most challenging alternatives to secularization theories, according to the state of the art -individualization -, examining it in the light of secularization's central assumptions. At the end of the paper, for a more systematic exam, we provide a table analysis comparing the main axioms of both theories.

Key-words: Secularization. Individualization. Comparative method.

\section{Las teorías de la secularización y de la individualización en análisis comparado}

\section{Resumen}

Se ha escrito mucho sobre secularización, pero hay pocas investigaciones profundas sobre las capas internas y alternativas más sólidas y sistemáticas que le siguieron. En nuestra opinión, eso significó dificultades de comprensión y profundización teórica y analítica que pueden ser superadas. Para atender tal necesidad, escogimos un diseño de investigación que engloba estrategias de descripción densa y el método comparativo. Dividimos el trabajo en dos partes esenciales. Primero analizamos los principales substratos de la secularización, sobre todo la diferencia funcional, la racionalización, la sociabilización, la seguridad existencial, la diversidad, igualitarismo e individualismo. En segundo lugar, introducimos la individualización, examinándola a la luz de sus presupuestos fundamentales. Al final del trabajo ofrecemos un cuadro de análisis con la comparación de los principales axiomas de las dos teorías.

Palabras clave: Secularización. Individualización. Método comparativo.

\section{Introdução}

Não obstante o debate sobre a secularização, tal o conhecemos, esteja presente e seja prolífero nas ciências sociais, sobretudo, desde a década de 1960; a maioria dos cientistas sociais continua a declarar dificuldades ao trabalhar com esse conceito.

Beckford, no Social Theory and Religion (2003), chegou a ponto de afirmar que a secularização é um caso paradigmático de um conceito essencialmente contestado que é, simultaneamente, central para o debate acadêmico e inerentemente problemático. No nosso entender, é precisamente nesse campo que se encontra a noção de secularização. O estado da arte testemunha a nosso favor. Glasner, no The Sociology of Secularisation (1977), e Stark (1999, p. 250), dizem que ela é um mito sociológico e uma profecia falhada; Fichter, no "Youth in search of the sacred" (1981) e Hadden (1987, p. 595) asseveram que ela é uma doutrina, uma 
ideologia ou um dogma inquebrável da teoria sociológica; para Gorski (2000, p. 139-140) e Tschannen, no Les théories de la sécularisation (1991), ela não é uma teoria, mas uma família de teorias ou um paradigma; Lechner, no "The Case against Secularization" (1991), a acusa de ser uma tese etnocêntrica do Ocidente, enquanto Asad, no Formations of the Secular (2003) afirma que ela representa uma narrativa determinista inaceitável. Enfim, para Casanova (1994, p. 12), a noção de secularização é tão multidimensional e ironicamente reversível nas suas conotações contraditórias que é praticamente inoperacional cientificamente. ${ }^{1}$

Chegados a este ponto, será apenas normal perguntar o que é a teoria(s) da secularização? Será possível (re)operacionalizá-la ao nível científico? Se sim, como?

É precisamente aqui, na resposta à última interrogação, que o nosso trabalho pretende situar-se. Muito se escreveu sobre a ideia de uma secularização unívoca; porém, poucos são os investigadores que procuram entender os seus substratos e, menos ainda, são aqueles que trabalham a secularização concomitantemente com as alternativas, mais sólidas e sistemáticas, que lhe seguiram. Mesmo nos casos em que isso sucedeu (GORSKI, 2000; STOLZ, 2010; POLLACK, 2011; PICKEL e SAMMET, 2012; ROBERTS e YAMANE, 2012), os esforços acadêmicos foram, essencialmente, descritivos, não problematizando suficientemente o objeto de estudo, nem estabelecendo comparações de forma sistemática, limitando-se, frequentemente, a observações genéricas sobre as proposições de alguns dos principais teóricos da secularização e de suas alternativas. ${ }^{2}$

Não negamos o contributo relevante desses trabalhos, em especial, em matéria de sistematização descritiva e analítica; contudo, consideramos que, nesse campo, é necessário e possível dar um passo à frente.

Visto que o nosso trabalho pretende examinar a ideia de secularização por meio das suas camadas internas, consideramos útil a aplicação do desenho de investigação da descrição densa (GEERTZ, 1973, p. 3-10). Ou seja, um tipo de explicação inteligível sobre os eventos sociopolíticos, as instituições e os processos que estimulam a secularização. Para cumprir tal desiderato, pensamos, como Collier (1993, p. 105 e 109) ou Smelser (2013 [1976], p. 2-3), que

\footnotetext{
1 Se bem que, neste caso, o autor se refere aos moldes dominantes de análise científica empírica.

2 Apesar de, nos trabalhos citados, existir uma preocupação com a questão comparativa; julgamos que, pela extensão das estruturas de análise propostas, eles acabam por ser exercícios científicos algo superficiais, nomeadamente no concernente à secularização, excetuando o trabalho de Roberts e Yamane, (2012, p. 325-342) e, ao nível histórico, o de Gorski (2000). Mas, também no que diz respeito às suas alternativas. Por exemplo, nos estudos restantes, são muito raras as citações diretas aos trabalhos dos seus principais teóricos.
} 
o método comparativo é uma ferramenta fundamental. Isto, porque aumenta o nosso poder descritivo, por meio da distinção entre similaridades e contrastes dos casos de estudo, e facilita o aprofundamento teórico-analítico e outras formas de compreensão interpretativa. Assim sendo, chamamos à colação a teoria da individualização que é, atualmente, segundo vários autores (POLLACK e PICKEL, 2009, p. 145-146; STOLZ, 2010, p. 255; POLLACK, 2011, p. 6-7; PICKEL e SAMMET, 2012, p. 9-12; PICKEL, 2012, p. 9-10), um dos modelos explicativos mais desafiantes ou uma das alternativas mais relevantes à secularização. ${ }^{3}$ Esse modelo corresponde a um esforço de formação de uma nova teoria geral, caracterizada por explicações sobre as orientações religiosas dos indivíduos, que argumenta que a religiosidade individual mantém uma importância constante, por contraste à relevância da religião institucionalizada que é variável e, na maioria dos casos, decrescente.

Posto isso, estabelecemos um plano de trabalho ancorado em quatro etapas essenciais. Em primeiro lugar, abordamos algumas questões conceptuais e históricas que subjazem ao advento da tese da secularização. Após essa etapa inaugural, entramos na análise dos seus substratos, examinando as suas múltiplas camadas internas. Depois, procuramos entender a teoria da individualização à luz das teses da secularização, privatização e desprivatização. A partir desse ponto, estamos preparados para entrar nas questões mais controvertidas da individualização, sendo capazes de examinar algumas das suas camadas internas mais relevantes. A perspectiva comparativa encontra-se presente desde a entrada nas teorias da individualização; porém, no epílogo do trabalho, para efeitos de sistematização, propomos um quadro comparativo dos principais axiomas dessas teorias.

\section{A(s) teoria(s) da secularização: proposta de análise das suas principais camadas internas}

A questão sobre qual o momento fundamental para o estabelecimento de um estudo sistemático do fenômeno religioso nas sociedades modernas - o se-

\footnotetext{
3 Não ignoramos a existência de outra alternativa teórica relevante à secularização: a teoria do mercado religioso ou da economia religiosa. Essa teoria, defendida por autores como Laurence Iannaccone, Rodney Stark, Roger Finke, Stephen Warner ou William Bainbridge, diz essencialmente que nas sociedades modernas existe uma procura social permanente por religião, mas que a vitalidade religiosa depende dos bens oferecidos pelas firmas religiosas (igrejas ou seitas) em atividade no mercado. No entanto, de modo a atingirmos o almejado grau de compreensão interpretativa profunda, não abordamos essa teoria em nosso trabalho.
} 
gundo período em nossa opinião ${ }^{4}$, , parece consensual dentro da literatura sobre a secularização.

Com efeito, a maioria dos autores menciona o período pós Segunda Grande Guerra (pós-1945) e os inícios da década de 1960 como momentos inaugurais para a teoria da secularização no campo da sociologia das religiões. Casanova (1994, p. 19), por exemplo, afirma que é nesse período que se podem encontrar as suas primeiras tentativas de desenvolver formulações empíricas e sistemáticas. $\mathrm{Na}$ opinião de Hellemans (1998, p. 67-68), isso deveu-se à publicação de três livros: Religion in Secular Society (1966), The Invisible Religion (1967) e The Sacred Canopy (1967). Mas, não apenas destes, segundo afirma Demerath, no trabalho "Secularization and Sacralization" (2007), porquanto a academia das ciências sociais da época produziu uma supersafra de publicações a respeito da secularização. O desenvolvimento teórico fez que a tese da secularização fosse integrada, durante os anos 1960, na teoria da modernização, tornando-se num dos seus axiomas centrais (GORSKI, 2003, p. 111). Para Hadden (1987, p. 594), na época, a tese da secularização parecia autoevidente; enquanto Gorski (2003, p. 111) insiste que todos pareciam concordar com a ideia de que a influência pública da religião estava diminuindo. A ideia de secularização ganhou relevo nos circuitos acadêmicos alemão, francês, inglês e norte-americano nesses anos, de acordo com Bremmer (2008, p. 434-437). A referência geográfica é simbólica, visto que, segundo Stark (1999, p. 251), a teoria da secularização "exprimia totalmente o estado de espírito desses tempos".

Mas, o que significa a expressão teoria da secularização? Em primeiro lugar, importa notar que não existe uma única teoria da secularização. A frase designa, essencialmente, um conjunto de ideias referentes à relação entre modernização e religião. Contudo, a sua multidimensionalidade pode conduzir a disputas e contradições acadêmicas sobre o seu significado que, por consequência, podem gerar incompreensões epistemológicas que, derradeiramente, tornam o seu sentido inoperacional cientificamente.

De modo a contornar tais dificuldades, propomos, à entrada do estudo das teorias da secularização, a aplicação de uma análise em camadas múltiplas. Por meio

4 Situamos o primeiro momento fundamental nos finais do século XIX. Realçamos, em particular, as respostas acadêmicas dos fundadores da sociologia à transmutação dos sistemas modernos e pré-modernos de sociedade e aos seus desafios intrínsecos, nomeadamente: Saint-Simon, Comte, Marx, Durkheim, Troeltsch, Tönnies e Weber. O seu estudo nos permite não apenas situar as primeiras interpretações sociológicas sobre o lugar da religião nas sociedades modernas; mas, também, as suas novas perspectivas escatológicas, as interpretações científicas inaugurais à relação religião-modernidade e, sobretudo, a gênese da teoria da secularização. 
dela conseguimos criar conceitos sistematizados que agrupam as suas principais correntes científicas, esperando, com esse refinamento metodológico, lograr uma maior clareza conceptual.

Em termos muito gerais, as teorias da secularização afirmam que o processo de modernização e os seus subprocessos, transformadores da totalidade da estrutura social, não podem decorrer sem consequências para as tradições e instituições religiosas. ${ }^{5}$ Ou seja, as propriedades estruturais da modernização, como a racionalização, a diferenciação funcional ou a socialização (Vergesellschaftung) colocam problemas à religião, pelo menos no seu sentido tradicional, e reduzem ou, no limite, extinguem a sua relevância social.

Vários autores consideram que, dentro desse marco teórico, o nível de análise mais importante ou, no mínimo, o mais evidente da secularização é o macrossocial ${ }^{6}$ (TSCHANNEN, 1992, p. 61; POLLACK, 2011, p. 8; ROBERTS e YAMANE, 2012, p. 341). Eles alegam que, de todas as dimensões analíticas da secularização, a macro é aquela que de fato ocorre em todas as sociedades ocidentais e que conduz a formas reais de mudança na religião institucionalizada. Ao nosso ver, é sobretudo dentro dessa dimensão que devemos entender os substratos da secularização.

\subsection{Diferenciação funcional}

O núcleo central dessa dimensão macrossocial é representado por uma teoria de diferenciação funcional de inspiração durkheimiana. ${ }^{7}$ Ela diz respeito ao pro-

5 Por exemplo, a urbanização e a erosão da civilização paroquial, normalmente associadas a fortes vínculos religiosos; a expansão da literacia e a educação e o fim do monopólio do conhecimento do clero; a ciência e a tecnologia e o desenvolvimento de caminhos alternativos aos religiosos para se compreender o mundo; as ideologias políticas e o surgimento de novos princípios reguladores e legitimadores da ação estatal; o crescimento do Estado moderno e a centralização de funções oferecidas anterior e unicamente pelas instituições religiosas; a participação política dos indivíduos e a sua relativa emancipação do controle das elites políticas e religiosas; a prosperidade e a modernização econômica e o sentimento de segurança existencial que levam os indivíduos a recorrer menos à religião; a mobilidade e as migrações internacionais e o desafio que colocam aos monopólios religiosos. Alguns desses pontos são trabalhados explicitamente pelos autores e pelas teorias que analisaremos em seguida.

6 O conceito de secularização macrossocial nasce da compreensão da ideia de laicização da sociedade em Karel Dobbelaere, no artigo "Secularization: A Multi-Dimensional Concept” (1981) - dimensão macro da secularização - da sua reconceptualização por Mark Chaves, no trabalho "Secularization as Declining Religious" (1994) - secularização societal - e da sua atualização por Veit Bader, na monografia Secularism or Democracy? (2007) - secularização política.

7 Veja The Division of Labor in Society (1893). 
cesso pelo qual o Estado e a política reduzem os sistemas religiosos tradicionais a um subsistema social, entre outros, fazendo-os perder a sua proeminência e relevância em sociedades modernas funcionalmente diferenciadas. Isto é, com o crescimento da autonomia, especialização, competição e tensão entre as diferentes forças sociais, as autoridades religiosas institucionalizadas perdem o controle sobre determinadas funções sociais, como: a política, economia, educação, família, saúde ou assistência social.

Como nos explica Hellemans (1998, p. 75), no estado da arte, o fenômeno da diferenciação per se não é discutivel. A questão principal não é tanto o acontecimento dos processos de diferenciação, mas as consequências que tiveram para o lugar da religião na sociedade moderna. Seguindo o modelo de Gorski (2000, p. 139-142), a partir da década de 1960, conseguimos detectar três posições básicas e não estanques: declínio, privatização e transformação.

A tese do declínio é uma das mais visíveis nos argumentos dos autores. Para Wilson (1969, p. xiv), por meio desse processo de diferenciação ou autonomização, a sociedade deixa de necessitar das funções latentes da religião e, por conseguinte, as instituições e as ações religiosas perdem a sua relevância social. Com o processo da diferenciação, o fenômeno religioso, em geral, e as autoridades e organizações religiosas, em particular, veem a sua relevância social ser circunscrita, diminuída ou até desintegrada (MARTIN, 1978, p. 3; LUHMANN, 1995, p. 191).

A proposição da privatização é, sobretudo, avançada por Luckmann (1967). Para o autor, a diferenciação funcional deriva de uma ação política deliberada de desenvolvimento de esferas institucionais especializadas (IDEM, p. 39-40, 101). A redução do espaço de ação e influência das instituições religiosas transformam a religião em uma realidade crescentemente subjetiva e privada (IDEM, p. 85-86). Outros autores partilham desse argumento. Em Berger (1990 [1967], p. 107), o fenômeno da diferenciação não provoca apenas mudanças socioestruturais na religião; antes, a religião passa a manifestar-se mais fortemente como retórica pública e virtude privada (IDEM, p. 134). Também Luhmann (1995, p. 218-221) considera que a criação e a especialização de subsistemas sociais seculares podem estimular a individualização das escolhas dos indivíduos.

Por fim, analisamos a ideia de transformação. Parsons, com a sua obra Structure and process in modern societies (1960), foi um dos primeiros a escrever sobre o processo de diferenciação e a respeito de suas consequências para a religião. Como Luckmann, ele acredita que, à medida que as sociedades se complexificam e se diferenciam funcionalmente, a influência institucional das igrejas ocidentais se confina gradualmente à esfera privada. Contudo, por oposição a Luckmann, 
Parsons acredita que a manutenção dos valores cristãos se mantém sadia nessas sociedades. Com efeito, ele afirma que esses valores passaram por um processo de generalização, formando o núcleo sagrado do sistema social e das suas partes constituintes. Assim, enquanto o sagrado ficou mais fragmentado, não se tornou, porém, menos público (PARSONS, 1977). Como Parsons, Berger (1990 [1967], p. 133) acredita que a religião tradicional continua a ter impacto público; porquanto, segundo Casanova (1994, p. 21), em condições de diferenciação estrutural, a religião passa a poder especializar-se exclusivamente nas suas próprias funções religiosas, logrando trabalhar em novos modelos de relação com os indivíduos e os Estados modernos; por exemplo, por meio do desenvolvimento de uma religião civil (BELLAH, 1975, p. 3, 168).

\subsection{Racionalização}

Jean-Paul Willaime, no artigo "La sécularisation: une exception européenne?" (2006), defende que a diferenciação constitui uma das consequências da racionalização e ambas são apontadas como fatores-chave da modernização que explicam a diminuição do significado macrossocial da religião.

Em traços gerais, a tese da racionalização, de inspiração weberiana, diz que a Reforma Protestante, o Iluminismo e a Industrialização desenvolveram uma perspectiva racional do mundo - ancorada em padrões empíricos de prova, conhecimento científico dos fenômenos naturais e domínio tecnológico do universo - que fez crescer uma cosmovisão racional que, por sua vez, enfraqueceu as fundações da crença no sobrenatural. A especialização de áreas de conhecimento, como a política, educação, engenharia, tecnologia, matemática ou a medicina, criaram um sentimento de controle lógico do ser humano sobre a natureza que dispensa as interpretações bíblicas ou metafísicas do mundo. A religião e os seus ensinamentos passam a ser apenas mais uma fonte de conhecimento, entre outras, das sociedades modernas, como sucede na tese da diferenciação.

A visão racionalista do mundo e o seu impacto na religião não ficam cristalizados em Weber. Muitos dos mais relevantes sociólogos avançam com essa perspectiva, em particular, a partir das décadas de 1960-1970, integrando-a nas teorias da secularização.

Na linha da The Protestant Ethic de Weber (1904-1905), Berger (1990 [1967], p. 105-125) assevera que a racionalização é um processo iniciado pelo judaísmo e pelo cristianismo (sobretudo o protestante). Não obstante as suas origens religiosas, Berger (IDEM, p. 43) pensa que a proliferação de justificações racionais e científicas reduz a credibilidade das explicações religiosas do mundo. Pelo fato de 
representar o pré-requisito central de qualquer sociedade moderna industrializada, o processo de racionalização é, em Berger (IDEM, p. 132-133), a variável decisiva da secularização. Para o autor, as razões para essa secularização de tipo macrossocial são: a especialização das organizações sociais e dos seus recursos humanos científicos e tecnológicos e a sua racionalização estrutural psicológica; o potencial secularizante abrangente da racionalidade capitalista industrial; o estabelecimento, ao nível estrutural, de uma burocracia estatal altamente racional e, ao nível ideológico, a manutenção de legitimações adequadas para o aparato burocrático (IDEM, p. 131).

Como Berger, Wilson (1976) segue a linha weberiana e estabelece uma forte relação entre secularização e racionalização. Para o autor, a racionalidade deriva dos avanços tecnológicos e científicos, sendo determinada por uma relação eficiente entre meios e fins, na qual qualquer pessoa pode desempenhar a sua função técnica de forma autônoma. É aquilo a que Luckmann (1967, p. 96) chama de anonimato dos papéis especializados, determinados por instituições funcionalmente racionais; ou ainda aquilo que Martin (1978, p. 83) denomina de relações impessoais e mecânicas, onde os laços íntimos de comunidade horizontal são quebrados. Assim sendo, o que predomina são as orientações racionais e empíricas do mundo, por oposição às orientações mágicas e religiosas (WILSON, 1976, p. 11). O controle é técnico e burocrático e não moral e religioso (IDEM, p. 20). Grosso modo, a racionalização reduz a frequência que as pessoas e os Estados se dirigem e buscam direção na religião, especialmente em matéria educativa (WILSON, 1969, p. 63-64) e em questões de família e natalidade, mas, também, na procura de determinados objetivos sociais (WILSON, 1982, p. 44).

Vários autores, da época, mas não apenas, partilham dessa ideia. Como sucede em Berger e Wilson, em Martin ou Stark e Finke o processo de racionalização não se circunscreve apenas às esferas política e econômica. Para os autores, a ciência e a consciência tecnológica são as principais perspectivas seculares autônomas do mundo que promovem um sentimento de controle e manipulação dos ambientes social e natural. Com efeito, elas são as que mais carregam consequências fatais para a religião, as que a tornam mais obsoleta e implausível, e as que mais restringem o papel da contingência, reduzindo a influência das suas propriedades metafísicas.

\subsection{Societalização}

Outro elemento clássico das teorias da secularização, apontado comumente pelo estado da arte, é a passagem de um sistema de base comunitária para outro de base social, ou seja, a societalização (Vergesellschaftung). 
Dentro dessas teorias, a versão original da societalização é a de Tönnies, na obra Gemeinschaft und Gesellschaft (1887), explicando que a transição da comunidade para a sociedade reflete a perda do domínio das instituições religiosas sobre o indivíduo. Essa tese foi, de forma implícita ou explícita, ecoada na literatura, designadamente por Wilson e Hervieu-Léger.

O argumento de Wilson (1976, p. 265-266) é que a secularização corresponde ao declínio da comunidade, ou seja, ela é concomitante com a societalização. Ao elaborar a sua tese, o autor explica que tradicionalmente a religião celebrava-se e se legitimava na vida local (comunitária). Contudo, com a passagem da comunidade a sociedade e com a sua organização, agora, à escala nacional, a plausibilidade global dos sistemas moral e religioso diminui, a religião se enfraquece e se distancia (WILSON, 1982, p. 153). Com efeito, Wilson (1976, p. 246) associa a societalização à modernização e aos seus inerentes processos de industrialização e racionalização. Para o autor, ela se refere ao fato de as formas de comunidade, sobre as quais a religião exercia um controle social significativo, tenderem a dissolver-se no processo de modernização, sendo substituídas por organizações e relações pessoais mais amplas e impessoais.

Também em Hervieu-Léger (1999, p. 203; 2000, p. 132-136), o processo de societalização traz consequências para a religião. Segundo a sua tese, com a transição de um sistema de base comunitário para outro de base societal, os indivíduos deixam de encontrar as suas ligações sociais num lugar permanente, algo que reduz a possibilidade de controle social e o sentimento de partilha de uma consciência coletiva (religiosa) institucionalizada num território específico. Para a autora, isso é um reflexo da erosão da civilização paroquial, i.e., a passagem de uma sociedade rural (que moldou a cristandade) para uma industrial que tende a causar problemas à cultura religiosa.

\subsection{Segurança existencial}

Aos três argumentos clássicos das teorias da secularização, indicados como elementos justificativos do decréscimo da relevância macrossocial da religião, decidimos juntar o axioma da segurança existencial de Norris e Inglehart (2004).

Essa adenda afigura-se coerente, porquanto a sua tese parte de dois pressupostos básicos da secularização: a transição de sociedade agrária para industrial (societalização) e o desenvolvimento de uma sociedade industrial para outra pós-industrial (racionalização) (IDEM, p. 35-36). Segundo os próprios autores, a sua teoria é uma atualização da versão clássica da secularização, baseando-se nos axiomas da segurança e das tradições culturais. Contudo, para efeitos do nosso 
estudo, o foco estará no primeiro. ${ }^{8}$

A sua premissa básica diz que existe uma relação muito próxima entre o processo de modernização, ou seja, os índices de desenvolvimento econômico, político e cultural e os valores de segurança existencial. ${ }^{9}$ Segundo Norris e Inglehart, a modernização reduz as ameaças de sobrevivência que são comuns em sociedades em desenvolvimento, em particular entre os estratos mais pobres, e, por consequência, esse sentimento de segurança reduz a necessidade de apelo ao amparo que a religião oferece (IDEM, p. 53).

De acordo com alguns autores (PICKEL e SAMMET, 2012, p. 9), o seu argumento reproduz, em certa medida, as concepções marxistas que declaram que os sentimentos de vulnerabilidade dos indivíduos, em face de ameaças existenciais, são um fator-chave para direcionar a religiosidade. De fato, em Norris e Inglehart, índices elevados de segurança existencial tendem a diminuir a ansiedade e promovem sentimentos de bem-estar psicológico (IDEM, p. 19). Por meio do reforço dessas sensações de confiança, os processos de modernização societal, desenvolvimento humano e igualdade socioeconômica trazem consequências significativas para a religiosidade. As condições de crescente segurança que normalmente acompanham a transição das sociedades agrícolas para industriais (momento mais dramático de mudança) e depois para pós-industriais (processo de mutação menos pronunciado), tendem a reduzir a saliência da religião na vida das pessoas. Ou seja, os indivíduos tendem a tornar-se menos obedientes a líderes religiosos tradicionais e a colocar menos importância em práticas religiosas convencionais. Para os autores, esses efeitos operam tanto ao nível societal como individual; porém, consideram que o primeiro é mais importante (IDEM, p. 18).

\subsection{Diversidade, igualitarismo e individualismo}

Steve Bruce é um dos principais representantes da tradição neo-ortodoxa da secularização. A sua posição (BRUCE, 2002, p. 8-29; 2011, p. 27-56) quanto aos

\footnotetext{
De forma sumária, podemos dizer que o axioma das tradições culturais assume que as distintas cosmovisões, originalmente ligadas às tradições religiosas, moldaram a cultura de cada país de uma forma duradoura. Atualmente, esses distintos valores continuam a ser passados aos cidadãos; porém, eles já não são transmitidos principal ou exclusivamente pelas organizações religiosas, mas pelo sistema educativo ou pelos mass media de cada país (IDEM, p. 17).

9 Para os autores, dentro desses valores de segurança deve estar, acima do desenvolvimento puramente econômico, o desenvolvimento humano. Este mede-se por meio de indicadores como: acesso igual à escolarização e à literacia, cuidados de saúde básicos, nutrição adequada, acesso à água potável ou rede social mínima para os grupos mais carentes (IDEM, p. 64).
} 
efeitos dos processos da modernização sobre a religião é abrangente e complexa (dividida em três eixos principais e com mais de vinte pontos inter-relacionados entre si) e engloba a totalidade dos pressupostos clássicos supramencionados. De modo a tornar a nossa análise operacional, observaremos com maior detalhe o eixo central, aquele que deriva diretamente da ética protestante, do capitalismo industrial e do crescimento econômico, pois é o que aparenta ter mais implicações ao nível macrossocial para a religião. Contudo, também consideraremos os dois outros eixos através das lentes do individualismo e do racionalismo, procurando entender como se ligam à tese central.

Em linhas gerais, o argumento principal de Bruce (2002, p. 30; 2006, p. 37) diz que a secularização, ou melhor, o declínio ou a marginalização da autoridade das crenças religiosas, deriva da combinação de três fatores: individualismo, diversidade e igualitarismo. Bruce, como sucede em Norris e Inglehart, inspira-se em Marx, em especial na sua teoria da formação de classes. À medida que as funções sociais se tornam progressivamente diferenciadas e as comunidades se tornam gradualmente societalizadas, as pessoas dividem e se afastam umas das outras. Bruce (2006, p. 37) vai beber ao conceito bergeriano de pluralização das cosmovisões individuais, justificando que a diferenciação estrutural foi acompanhada por uma diferenciação social (BRUCE, 2002, p. 9; BRUCE, 2011, p. 34). Assim, com a proliferação de novos papéis sociais e com a crescente mobilidade, os pressupostos morais e metafísicos comunitários tradicionais fragmentam-se e, por consequência, a comunidade transforma-se numa variedade de grupos heterogêneos que competem entre si.

Esse fenômeno gera, segundo Bruce (2002, p. 4; 2011, p. 27), uma situação de profunda diversidade social e cultural que, desembocando num pluralismo religioso, apresenta dois resultados concomitantes fundamentais. O primeiro é o princípio do igualitarismo. Para o autor, é com o tema da diversidade nas sociedades industriais que faz sentido falar de igualdade (BRUCE, 2002, p. 11; BRUCE, 2006, p. 37). Segundo o argumento, uma das consequências fortuitas da Reforma Protestante foi a reafirmação do que estava implícito desde os inícios do cristianismo: todas as pessoas são iguais aos olhos de Deus. A igualdade perante Deus evoluiu para uma equidade entre humanos, desdobrou-se numa igualdade diante da lei e culminou numa equidade de direitos individuais (BRUCE, 2002, p. 11). A questão do individualismo ganha pertinência, precisamente aqui, em articulação com o igualitarismo, por causa das dinâmicas autônomas que cada um desenvolveu e dos seus resultados indiretos produzidos pela Reforma (BRUCE, 2011, p. 31-33). Em especial, a promoção de um espírito individualista (semelhante ao do fenômeno 
da societalização) e de uma dissidência religiosa (no sentido tradicional), além do crescimento das seitas e do voluntarismo da associação religiosa.

Segundo Bruce, é exatamente através do igualitarismo e do individualismo que a Reforma estabelece as bases da democracia liberal. Os seus argumentos religiosos promoveram um individualismo, igualitarismo e uma diversidade que, por seu turno, se associaram às crescentes diferenciações sociais e estruturais que levaram, enfim, os governos a seguir na direção das democracias liberais seculares (BRUCE, 2011, p. 39). Ou seja, o estabelecimento desse sistema plural e igualitário forçou a secularização do Estado - a sua separação das igrejas (BRUCE, 2002, p. 16-17). Este é o segundo resultado da diversidade: o estabelecimento de Estados seculares e da democracia liberal. Face ao crescente pluralismo religioso, os Estados que reconhecem a igualdade legal dos indivíduos são forçados a retirar o seu apoio a organizações religiosas específicas e a secularizar as suas instituições centrais. Eles se tornam progressivamente neutros, em termos religiosos, e as religiões institucionalizadas são abandonadas ou neutralizadas (BRUCE, 2002, p. 21; BRUCE, 2011, p. 49).

A esses dois resultados fundamentais, consideramos que se devam ainda acrescentar o crescimento da ciência e da tecnologia e o desenvolvimento da consciência tecnológica; em suma, a racionalização. Em Bruce (2002, p. 26-28; 2006, p. 37; 2011, p. 43-37), a ciência e a tecnologia não apenas aumentam o nosso conhecimento e o sentimento de controle do mundo em que vivemos, como também, mudam o nosso modo de pensar. Em particular, afetam o imaginário naturalista e, por meio da sua racionalidade subjacente e da sua autossugestão de valorização humana, as pessoas tornam-se menos susceptíveis de aceitar a noção de uma força divina externa.

Resumidamente, em Bruce (2002, p. 30; 2011, p. 45, 49), a diversidade, o individualismo, o igualitarismo, a democracia liberal e a ciência e tecnologia, entre outros, contribuem para um sentimento geral de autorrelevância e liberdade de crença que transforma a religião tradicional (autoritária e dogmática) menos atraente para as sensibilidades modernas. O autor conclui então que, face aos avanços dos processos da modernização, a religião sai enfraquecida, perdendo a sua plausibilidade social (BRUCE, 2002, p. 29-36).

\section{A teoria da individualização: entre secularização, privati- zação e desprivatização}

Para Pickel (2012, p. 9), nas reflexões científicas sobre o lugar e futuro da religião no mundo moderno, a secularização foi, entre os finais da década de 
1960 e os inícios do século XXI, o paradigma dominante. O argumento de que o processo de modernização, incluindo alguns dos seus subprocessos já analisados - racionalização, diferenciação funcional ou ausência de ameaças existenciais -, não se coaduna com a religião e conduz a uma contínua perda de relevância social da religião, teve ressonância particular nas ciências sociais do Ocidente, em especial nas europeias.

Todavia, esses pressupostos foram progressiva e mais sistematicamente questionados nas últimas décadas. Isso sucedeu, essencialmente, por dois motivos. Em primeiro lugar, verificou-se que o crescimento de novos movimentos religiosos e de formas individualizadas de religião, desenvolvidos fora da esfera das igrejas tradicionais, podiam ser observados em qualquer região do mundo (HERVIEU -LÉGER, 1999; ROOF, 2001). Em segundo lugar, começou-se a contestar o foco excessivo da análise e interpretação das taxas de frequência a serviços religiosos públicos. Essa concentração dificultava a observação de informações sobre as eventuais variações na religiosidade privada ou individual (LUCKMANN, 1967, 1991; DAVIE, 1994).

Essas críticas à secularização e às suas subsequentes sistematizações teóricas viriam a ser designadas, em sociologia das religiões, de teorias da privatização ou individualização da religião que, pela sua importância teórica, serão analisadas em seguida. O seu exame é particularmente relevante, pois nos permite entender qual a resposta aos processos de diferenciação, societalização ou pluralismo a um nível micro. Ou seja, possibilita-nos a compreensão das implicações em matéria de atitudes, condutas e valores religiosos à escala pessoal.

Antes de abordarmos diretamente essa questão, achamos pertinente a distinção entre os conceitos de privatização e individualização. Não obstante, autores como Willaime, na obra Europe et Religions (2004), afirmem que as teses têm um significado próximo; outros, como Hellemans (1998, p. 74), apontam diferenças quanto aos seus efeitos. Tendemos a concordar com a segunda posição. A tese da privatização afirma que a religião nas sociedades modernas não se situa nas instituições públicas, mas na esfera privada da família e do indivíduo, sugerindo, contrariamente à tese da individualização, que as religiões organizadas renunciam ou perdem todas as suas funções públicas ou políticas, tornando-se irrelevantes na esfera pública.

Ora, segundo o estado da arte, isso não é o que vem sucedendo no mundo moderno. Daniel Bell, no estudo "The return of the sacred?” (1977), admite que com a modernização houve uma diminuição da autoridade institucional das igrejas acerca das esferas da vida pública e um recuo para o mundo privado onde 
as religiões têm apenas autoridade sobre os seus fiéis. Todavia, isso não significa, necessariamente, um declínio na extensão, relevância e influência social das crenças individuais. Um dos autores que trabalha mais assertivamente essa ideia é Casanova (1994, p. 5-6). Por intermédio do seu conceito de desprivatização da religião, o autor argumenta que as tradições religiosas se recusam a aceitar o papel marginal e privatizado que as teorias da secularização e modernização lhes reservaram. Ao resistirem aos processos de secularização e modernização, as religiões continuam a operar na esfera pública e a ter impacto político nas sociedades modernas (BECK e BECK-GERNSHEIM, 2002, p. 26). Sintomática é a proliferação do sagrado, afirmada por Jacques Ellul em The New Demons (1975), e o seu crescimento e explosão (HERVIEU-LÉGER, 1999, p. 64-65; KNOBLAUCH, 2008, p. 149), mesmo em condições de intensa modernização. A religião, longe de perecer, tem nas sociedades modernas um lugar importante (HERVIEU-LÉGER, 1999, p. 302).

Esses argumentos não devem ser lidos como sinônimos de dessecularização, regresso da religião ou ressacralização. Ao contrário, devem ser entendidos como uma transformação da religião a um modo compatível com a forma atual da modernidade, levando sobretudo em consideração a crescente importância das subjetividades. Por esse motivo, segundo Hellemans (1998, p. 74), faz mais sentido falar de tese da individualização, porquanto aponta mais rigorosamente para a nova localização da religião na sociedade moderna: o indivíduo. Além disso, a individualização, contrariamente à privatização, não tem de estar associada à secularização; isto é, pode, mas não tem de, terminar em secularização. Assim sendo, em vez de ser uma dimensão da secularização, a individualização assumese como alternativa teórica ${ }^{10}$ (PICKEL e SAMMET, 2012, p. 9-10) - uma forma distinta de conceptualizar o papel da religião na sociedade moderna.

Similarmente às teorias da secularização, a teoria da individualização argumenta que a diferenciação funcional, racionalização e pluralização cultural são o ponto de partida para mudanças macrossociológicas. Não obstante reconheça o impacto da modernização na religião, a teoria da individualização distingue entre os seus efeitos na religiosidade orientada para as igrejas e comunidades religiosas (institucionalizada) e a religiosidade privada (individual) (BECK, 2010, p. 40).

10 Para Pollack e Pickel, no artigo "Religiöse Individualisierung statt Säkularisierung?" (2000), a individualização é uma falsa alternativa à secularização, dado que a segunda ocorre, por vezes, por meio dos próprios processos da primeira. Os autores destacam, em especial, a desinstitucionalização das formas de religião e o subsequente crescimento da indiferença ou da rejeição à religião (institucional) ou o surgimento de crenças mais difusas e individuais. Segundo o seu argumento, a tese da individualização deve, por isso, ser considerada como um aspecto parcial das teorias da secularização (IDEM, p. 247). 
Enquanto as teorias da secularização defendem um declínio em ambas, a individualização espera que isso suceda apenas nas suas formas institucionais, negando um enfraquecimento da religiosidade individual, mas confirmando uma mudança nas suas formas e expressões.

Isso sucede, porque a teoria da individualização utiliza um conceito de religião diferente. Para os teóricos da individualização, a noção de religião usada pela secularização é muito restrita, pois centra-se em questões relacionadas com a sociologia das igrejas, bem como em concepções substanciais de religião que não se coadunam mais com sociedades modernas funcional e socialmente diferenciadas. Em particular, foca-se em um conceito cristão de religião que limita as análises a fenômenos religiosos convencionais, perdendo a perspectiva de novas formas de religião. Por seu turno, a teoria da individualização, similarmente ao modelo do mercado religioso, concebe a religiosidade individual como uma constante antropológica que é inerente à natureza humana (LUCKMANN, 1967, p. 69; LUCKMANN, 1971, p. 75; PICKEL, 2012, p. 74). Assim, todos os fenômenos religiosos ou espirituais de significado superior podem ser incorporados na esfera da religião. ${ }^{11}$ A abrangência desse conceito permite, ${ }^{12}$ então, aos seus teóricos defender que, mesmo quando os conteúdos religiosos desaparecem, a tensão primária entre a finitude da vida humana e a infinidade das suas possibilidades permaneçam e promovam um dinamismo inexorável de procura de conteúdos religiosos (POLLACK, 2011, p. 14).

Feitas as distinções entre a individualização e os seus conceitos contíguos, julgamos estar em condições de penetrar na teoria da individualização propriamente dita, explorando, em detalhe, algumas das suas mais proeminentes subteorias.

\subsection{As teorias da individualização}

O estado da arte (HOWARD, 2007, p. 2; STOLZ, 2010, p. 255; PICKEL e SAMMET, 2012, p. 9-11) parece unânime na afirmação de que a teoria da individualização da religião surge da combinação da tese da privatização de Luckmann (1967) e da tese da individualização de Beck (1992). Essa evolução na teoria sociológica deu-se, porque, contrariamente aos pressupostos luckmianos, a religião não se está a tornar invisível, mas apenas ajustável à forma moderna de

11 A religião e religiosidade podem ser encontradas em contextos previamente insuspeitos, como: a psicanálise, nas culturas do corpo e do lazer, em comunidades de culto, no turismo ou no desporto.

12 Pollack, na obra Säkularisierung -- ein moderner Mythos? (2003), e Stolz (2010, p. 255-256) criticam a excessiva abrangência dessa definição funcional de religião, porque prejudica a análise da variação da relevância social da religião. 
socialização do indivíduo (IDEM, p. 121-252).

Grosso modo, a teoria da individualização diz que a modernização, em geral, e a diferenciação social, em particular, dissolveram o elevado grau de homogeneidade religiosa, mas não só, e as estruturas tradicionais das sociedades pré-modernas. Por consequência, os indivíduos se emanciparam da custódia das grandes instituições religiosas e, com isso, se tornaram livres para decidir com base nas suas próprias cosmovisões e orientações espirituais. Dotados de uma maior responsabilidade biográfica, eles passam a adotar um estilo de religião mais heterodoxo, sincrético e individual. Ou seja, enquanto nas sociedades pré-modernas a religião se encontrava institucionalizada nas igrejas, atualmente, essas instituições e as suas prescrições normativas e compulsórias não determinam com a mesma força a espiritualidade dos indivíduos.

Apesar da sua aparente consistência e coerência internas, o debate sobre a individualização é complexo e difícil de sumarizar (HOWARD, 2007, p. 2-3). Como sucede com a teoria da secularização, a teoria da individualização tem várias correntes endógenas. Acreditamos ser, portanto, mais útil analiticamente e correto cientificamente falar de teoria(s) da individualização no plural. Com efeito, a sua diversidade interna nos leva a escolher algumas das suas subteorias principais, nomeadamente: a religião invisível, a religião vicária, a espiritualidade reflexiva e a perda de memória coletiva. Nesta parte do trabalho, desejamos analisá-las separadamente, sistematizá-las e compará-las à luz das suas diferenças internas.

\subsubsection{Privatização da religião (ainda) e religião invisível}

Alguns autores (CASANOVA, 1994, p. 35; HELLEMANS, 1998, p. 74) afirmam que Luckmann e Luhmann são os sociólogos que apresentam formulações da teoria da individualização com mais semelhanças com a ideia de privatização. Em particular, com as suas três premissas essenciais: individualização da religião e a sua irrelevância na esfera pública; a fusão sincrética e individual de elementos religiosos tradicionais ou novos; e o declínio da religião institucional organizada (tradicional). Apesar de os autores nunca afirmarem explicitamente a segunda metade da primeira premissa, a proximidade da teoria da individualização com as noções de privatização e invisibilidade do religioso nos obriga a uma análise mais cuidada deste tópico.

Ao falarmos de privatização, Luckmann é um autor incontornável. A sua teoria baseia-se na diferenciação institucional e de funções sociais. Ela está essencialmente preocupada com o estudo da influência da especialização e fragmentação das várias esferas institucionais nas consciências individuais. Seguindo a linha de 
Wilson $(1969,1976)$, o autor afirma que esses fenômenos tornaram a religião numa realidade crescentemente subjetiva e privada (LUCKMANN, 1967, p. 85-86). Por conta da segmentação institucional, as organizações religiosas passam por um processo de diferenciação e especialização que tem repercussões profundas dentro da consciência humana, transmitindo mormente um maior sentido de subjetividade, autonomia, liberdade e comunalidade. Com a compartimentação do mundo e a dissolução da comunidade e de uma hierarquia de significado transcendental, o indivíduo ganha autonomia para guiar as suas escolhas, em matéria de significações derradeiras, com base na sua "biografia social” (IDEM, p. 99). A redução dos constrangimentos tradicionais e a maior liberdade de escolha desenvolvem no indivíduo uma postura de consumidor. Ele passa a encarar os bens sociais e culturais (religiosos e/ou seculares), disponíveis nas sociedades modernas, como um comprador que pode adquirir uma vasta gama de representações religiosas (LUCKMANN, 1967, p. 104). Por meio delas ele (re)constrói (sozinho ou com outros) um sistema estritamente individual de significações últimas (IDEM, p. 98-99). É uma espécie de bricolagem religiosa, melhor dizendo, um modo de religiosidade autoconstruída a partir de vários fragmentos que, na tentativa de construção de um todo de significações derradeiras subjetivas, podem, mas não têm de, estar ligados aos tradicionais universos simbólicos (IDEM, p. 109).

Luhmann, Parsons e Bellah aprofundam a tese funcionalista de Luckmann. Em traços gerais, ambos concordam que a privatização da crença é uma resposta da religião à crescente complexidade e diversidade da sociedade industrial moderna. Todavia, em Luhmann, isso sucede por conta de quatro fatores: diferenciação funcional, segmentação, estratificação e mobilidade social e geográfica; enquanto para Parsons e Bellah, isso ocorre por causa da própria evolução e complexificação da esfera religiosa. ${ }^{13}$ Não obstante partam de premissas diferentes, eles chegam à mesma conclusão de Luckmann: a privatização das decisões dos indivíduos em matéria de significações últimas de vida. Seguindo o argumento de Luhmann, as instituições religiosas perdem a sua força social em favor de subsistemas arreligiosos. A sua competição, a sua relativa autonomia e a sua incapacidade ou falta de vontade para integrar as diferentes cosmovisões religiosas numa única dimensão normativa prescritiva conduziram a uma consciência autopoiética que estimula a individualização das escolhas religiosas (LUHMANN, 1995, p. 220-221). Também em Parsons e Bellah a redução da influência das instituições religiosas sobre os indivíduos e a transformação da religião num assunto privado, cons-

13 Bellah (1964, p. 361-374), em particular, descreve essa evolução em cinco etapas: religião primitiva, arcaica, histórica, pré-moderna e, enfim, moderna. 
truída a partir de escolhas individuais livres, geram uma conjuntura na qual eles desenvolvem uma autoconsciência que os conduz à individualização e privatização religiosas (PARSONS, 1973; BELLAH, 1985).

Em Luckmann (1990, p. 127-138), tudo isso pode ser resumido na expressão transcendência em encolhimento. Ou seja, as novas formas sociais de religião partem das, anteriormente predominantes, grandes transcendências (experiências nãoquotidianas de alteridade que se encontram essencialmente ausentes das vidas dos indivíduos); transformam-se em transcendências intermédias (experiências de outros seres humanos que são simultaneamente perceptíveis e não-perceptíveis); e culminam em transcendências pequenas (baseadas nos limites temporais e espaciais das experiências quotidianas) (LUCKMANN, 1991, p. 176-179).

Subjaz à teoria desses autores a ideia de que forma social da religião pode perder influência; porém, a religiosidade individual modifica meramente a sua forma. Esta não tem, necessariamente, de se manifestar de forma pública. Ao contrário, pode resultar numa religião invisivel (LUCKMANN, 1967), uma nova forma de religiosidade que pode tomar contornos completamente diferentes daqueles tradicionalmente associados às instituições religiosas. A religião torna-se numa matéria subjetiva do coração, focada na autenticidade das experiências individuais (BELLAH, 1985, p. 250); ou seja, numa religião invisível do coração caracterizada por um tipo de religiosidade nova era - invisível, privatizada e pós-convencional.

\subsubsection{Do crer sem pertencer à religião vicária}

Davie (1994), ao tentar responder às pistas levantadas por Luckmann e demais autores sobre a forma da religião nas sociedades modernas, constata um profundo desencontro entre as taxas de crença individual e os índices de prática religiosa institucional. Constatado o paradoxo, a autora cunha a expressão crer sem pertencer (believing without belonging) para descrever essa nova forma de religiosidade não institucionalizada.

Esta tornou-se numa das fórmulas mais citadas e influentes em sociologia das religiões, ${ }^{14}$ sendo, para vários autores, a melhor imagem para representar a orientação religiosa nas sociedades modernas, especialmente as europeias ocidentais cristãs (POLLACK e PICKEL, 2009, p. 145; PICKEL e SAMMET, 2012, p. 10; DAVIE, 2013, p. 140-143).

14 Uma fórmula semelhante pode ser encontrada na obra Spiritual, But Not Religious de Robert C. Fuller (2001). Ao comprovar a discrepância entre os níveis de religiosidade tradicional e a espiritualidade individual, o autor cunha o termo espiritual, mas não religioso para descrever as pessoas que creem, mas que não pertencem a uma religião institucional. 
Todavia, esse conceito afigurava-se mais descritivo do explicativo, apoiandose muito sobre estatísticas de um fenômeno que parecia muito mais complexo do que isso. Por esse motivo, Davie adotou uma postura analítica mais qualitativa e sutil para expor a ambiguidade europeia: as igrejas históricas não desempenham mais um papel preponderante na vida quotidiana dos indivíduos; porém, isso não significa que elas deixem de desempenhar, de forma vicária, papéis morais, espirituais e sociais a favor da sociedade, mantendo-se assim relevantes socialmente (DAVIE, 2007, p. 137-138).

A autora utiliza o conceito de religião vicária (DAVIE, 2006, p. 24-27; 2007, p. 126-128, 137-138, 140-143; 2013, p. 128-129, 143-145) para explicar esse aparente paradoxo. Por meio dessa ideia, Davie pretende descrever uma atitude na qual a religião é desenvolvida por uma minoria ativa, mas em representação de uma maioria. Ou seja, a religião vicária evidencia a vontade das pessoas (que não praticam a religião tradicional-institucional diariamente) para delegar a esfera religiosa aos ministros profissionais das igrejas, entre outros, de modo a que eles desempenhem vicariamente funções religiosas em nome da população como um todo. Podemos distinguir quatro tipos de religião vicária na formulação davidiana: i) igrejas e líderes religiosos desenvolvem rituais em nome de outros; ii) líderes e praticantes religiosos creem em nome de outros; iii) líderes e praticantes religiosos encarnam códigos morais em nome de outros; e iv) igrejas como espaços de debate vicário sobre temas sociais controversos.

A religião vicária é, portanto, desenvolvida por outros em ocasiões raras, mas especiais (por exemplo, batizados, casamentos e, sobretudo, enterros ou em grandes momentos de celebração ou comoção coletiva). As igrejas e os seus ministros de culto mantêm-se relevantes socialmente, porquanto as pessoas requisitam as suas funções de mediadores do sagrado. A religião torna-se um bem público, disponível a todos, que deve ser mantido e apoiado pelos Estados para oferecerem religião vicária quando for requisitada (DAVIE, 2007, p. 219; DAVIE, 2013, p. 225).

Davie (2006, p. 27-29) conclui que há uma profunda mudança na natureza e na compreensão da religião nas sociedades europeias modernas. Passou-se de uma cultura de obrigação ou dever religioso para outra de consumo e escolha individual, como Luckmann denunciara. Aquilo que era simplesmente imposto, transmitido ou herdado torna-se uma questão de preferência pessoal.

A atomização da crença reflete, em Davie (2013, p. 61), a deficiência do atual processo de transmissão e uma ruptura na corrente de memória religiosa, na expressão de Hervieu-Léger (2000). Davie (2002, p. 18), inspirada nos teóricos da privatização, argumenta que as igrejas tornaram-se incapazes de oferecer um dossel sagrado. Deixaram de ser capazes de garantir uma memória coletiva religiosa que 
oriente as dinâmicas comunitárias. ${ }^{15}$ Por consequência, não se pode mais supor que a religião é passada entre os membros da comunidade através de uma série de correntes relacionais.

A igreja passa a ser entendida de fato, senão sempre de jure, como uma instituição de adesão voluntária, isto é, que se situa na esfera das escolhas individuais (IDEM). Essa questão é relevante, porque, por um lado, reduz os níveis de autoridade, influência e fidelização religiosa nos indivíduos e aumenta as tendências do crer sem pertencer e da religião vicária. Por outro lado, ela banaliza as organizações religiosas e os seus serviços de mediação com o sagrado. Estes passam a ser utilizados mediante as vontades pragmáticas, utilitárias e não necessariamente religiosas dos indivíduos.

\subsubsection{Espiritualidade reflexiva}

A teoria da espiritualidade reflexiva parte de um pressuposto básico: o conceito de secularização é demasiadamente simples para descrever o complexo fenômeno religioso moderno (ROOF, 2001, p. 75).

As sociedades modernas são marcadas social e culturalmente por sete características fundamentais: racionalização e diferenciação social, descredibilização e implausibilidade da religiosidade institucional, concepções destradicionalizadas do religioso, ênfase na individualidade, impacto dos media, a globalização e a maior abertura e diálogo das religiões católica, judaica e protestante (IDEM, p. 12, 65). Em conjunto, essas mudanças conduziram ao enfraquecimento da religião institucionalizada e a um reforço da autonomia individual do indivíduo em matéria religiosa, como as duas últimas subteorias analisadas argumentaram.

Os indivíduos tornam-se mais plásticos e multidimensionais. Surge a necessidade de procurar novos recursos religiosos, isto é, outro estilo de espiritualidade adaptável às circunstâncias modernas. Ao analisar o impacto dessas mudanças na religiosidade da geração baby boomer, Roof (IDEM, p. 12) identifica um fenômeno que designa de espiritualidade reflexiva. Uma forma mais intencional e autodirecionada de cultivar a sensibilidade espiritual que é diferente, funcionalmente, da consciência religiosa que conhecemos no passado. ${ }^{16}$

15 No entanto, na concepção de Davie, as igrejas são capazes de manter, vicariamente, parte dessa memória coletiva.

16 Segundo Roof (1997, p. 96), a palavra religião tem uma conotação negativa ou é vista com ceticismo pelos indivíduos modernos, sobretudo os jovens. $\mathrm{O}$ autor prefere o uso do termo espiritualidade por oposição à expressão religiosidade, porque o conceito de espiritualidade reflexiva engloba um conjunto de dinâmicas pessoais e coletivas muito mais complexas do que aquelas associadas com a religião antigamente (ROOF, 2001, p. 80). Essa opinião é também partilhada por Knoblauch (2008, p. 141-142). 
Desenvolve-se um tipo de religiosidade correspondente às formas sociais do espaço e tempo da vida de cada indivíduo. Isso lhe exige uma maior reflexividade sobre a própria vida, acerca de suas experiências e pressupõe um profundo autoconhecimento. Segundo Beck (2010, p. 16), os indivíduos usam as suas experiências religiosas para construir um dossel sagrado. Eles formam um novo tipo de religiosidade: o nosso próprio Deus (god of one's own) (BECK, 2010) ou a igreja do individuo solitário (ROOF, 2001, p. 65), construída na medida das suas necessidades espirituais.

De acordo com Besecke (2001), essa espiritualidade reflexiva engloba simultaneamente um compromisso com a racionalidade e com o valor do significado do transcendente. Ou seja, é um recurso cultural para criar significações sagradas que guiem as sociedades racionalizadas. A espiritualidade reflexiva está preocupada com a criação e sustentação de identidades mais completas. Corresponde a um processo orientado que pressupõe um potencial de crescimento e desenvolvimento humano (ROOF, 1997, p. 95). ${ }^{17}$ Enfim, ela se torna na forma comum de religiosidade individual. A linguagem cultural à qual os indivíduos hodiernos recorrem para se entenderem quanto ao significado do transcendente (BESECKE, 2001, p. 365).

À medida que o discurso religioso muda, também se alteram as expressões do ego, entendido como o núcleo de personalidade do indivíduo. Para Roof (2001, p. 66s.), a espiritualidade reflexiva conduz à expansão do ego (expansive self), na qual o indivíduo assume deliberadamente uma postura de exploração da sua vida interior, procurando respostas, sentidos e significados morais para a elaboração do seu ego. É, na expressão de Lifton (1999, p. 1-11), um ego proteu (protean self), moldável, fluido e multidimensional - um processo de contínua (re)criação psicológica individual -, adaptável aos diferentes contextos sociais. De acordo com Roof (2001, p. 66), a expansividade, o proteanismo e, acrescentamos nós, a racionalidade, citada por Besecke, afiguram-se como boas descrições de uma psique religiosa contemporânea caracterizada por expansionismos subjetivistas e pela procura de uma identidade interior autêntica, desenvolvida por meio de uma abordagem instrumental da religião (visando a autorrealização) e lograda por meio de uma procura espiritual individual.

Como asseverado pelas teorias de Luckmann e Davie, os conceitos de espiritualidade reflexiva e expansividade do ego remetem para o crescimento de uma

Um sintoma desses processos e fórmulas racionais, desenhados para alimentar a espiritualidade reflexiva, é a proliferação de manuais how to ou de outros livros de autoajuda que promovem a expansão do ego dos sujeitos modernos, como veremos em seguida (ROOF, 2001, p. 242). 
cultura de consumo. É a imagem de uma geração (os baby boomers) que, ao crescer, se tornou altamente consciente de si mesma e assumiu uma postura consumidora - de satisfação dos seus caprichos e desejos - em matéria espiritual (IDEM, p. 67). Isso não deve ser entendido como uma erosão do fenômeno religioso. Como sucede nas teorias da privatização e do crer sem pertencer, o que pode parecer deserção é frequentemente descompromisso ou divergência e, segundo Roof (IDEM, p. 153), dificilmente pode ser compreendido como uma ruptura completa com a fé pessoal ou, até, com os preceitos religiosos institucionalizados.

\subsubsection{Ruptura na corrente de memória coletiva}

Essa subteoria é mais uma tentativa de identificação e refinamento dos instrumentos conceptuais necessários para a compreensão da religião no mundo moderno. A tese da cisão da corrente de memória coletiva é muito devedora dos escritos de Danièle Hervieu-Léger. Como qualquer teórico da individualização, a autora interessa-se mais pela recomposição do que pela decomposição dos fenômenos religiosos. Hervieu-Léger estuda os possíveis eixos de reconstrução e de reidentificação de uma linha de crença religiosa compatível com as sociedades modernas, usando, para tal, uma abordagem diferente à dicotomia religião-modernidade levantada pelas teorias da secularização (HERVIEU-LÉGER, 1999).

Como sucede nas outras teorias da individualização analisadas, na concepção de Hervieu-Léger as sociedades modernas destroem certo tipo de vida religiosa (DAVIE, 2013, p. 60). Por conta dos efeitos da diferenciação, as sociedades ganham autonomia para se afastar da dominação dos sistemas religiosos que as controlavam, por meio de interpretações globais da vida humana. As sociedades passam a ser dominadas pelo imperativo da mudança. As vidas dos indivíduos tornam-se estruturalmente incertas, sendo permanentemente desafiadas pelos avanços da ciência e tecnologia. São sociedades desencantadas pela racionalização, mas onde um novo tipo de crença - tipicamente expansivo e proteu (ROOF, 2001; LIFTON, 1999), ou seja, fragmentado, fluido e móvel - prolifera (HERVIEU-LÉGER, 1998, p. 25-26; 2000, p. 163). Por oposição ao que sucedia no passado, as identidades religiosas dos indivíduos modernos não são mais herdadas dos seus genitores. Antes, são construídas individualmente, por meio de uma bricolagem de sentidos luckmiana, na qual o indivíduo isolado cria a sua própria religiosidade, baseando-se nas suas experiências e nos recursos simbólicos das tradições religiosas (HERVIEU-LÉGER, 1998, p. 25-26; 1999, p. 42-43). A individualidade religiosa moderna produz, para Hervieu-Léger (1999, p. 90-98, 121-131), duas figuras reveladoras do espírito da nossa época: o peregrino e o convertido. Não 
obstante as suas diferenças, ambos remetem para a ideia de um cenário religioso em movimento e onde a adesão à(s) nova(s) religião(ões) se baseia no voluntarismo associativo. É um novo tipo de religião nova era (new age). Uma crença religiosa totalmente centrada nos indivíduos e na sua realização pessoal e caracterizada pela primazia conferida à experiência pessoal que os guia de acordo com as suas próprias cosmovisões (HERVIEU-LÉGER, 2001, p. 164).

Em Hervieu-Léger (1999, p. 157; 2001, p. 162), a individualização religiosa está no âmago da religiosidade contemporânea. A individualização significa a independência de cada um e a dissolução das comunidades tradicionais (HERVIEU-LÉGER, 1990, p. 40). A tradição, a pedra angular da religião, é posta em causa e, com isso, a natureza da transmissão regular de valores e de instituições entre gerações modifica-se (HERVIEU-LÉGER, 1999, p. 61-62). ${ }^{18}$

A preocupação da autora com a transmissão da herança religiosa tem a ver com a própria forma como concebe a religião. Para si o conceito deve ser entendido como memória (HERVIEU-LÉGER, 1999, p. 66-67) ou como uma corrente de memória (chain of memory) (HERVIEU-LÉGER, 2000, p. 121-129). Por isso, é possível analisar o processo de desregulação religiosa nas sociedades modernas através do fenômeno de desestruturação da memória coletiva (HERVIEU-LÉGER, 1998, p. 27).

De acordo com Davie (2002, p. 18), em Hervieu-Léger, as sociedades são hoje menos religiosas do que as tradicionais, porque são mais incapazes de manter uma memória coletiva que fundamente a sua existência religiosa. Para Hervieu-Léger (1998, p. 24-25), a religião tradicional tem, no presente, mais dificuldades em florescer por causa da complexidade do mundo moderno (o imperativo da mudança e do presente; a fragmentação de instituições de memória, como a escola, família ou igrejas; ou o imediatismo da comunicação promovido pelos media). Surgem fenômenos de desmembramento e atomização da memória coletiva que culminam numa amnésia social. As sociedades tornam-se menos capazes, do que no passado, de produzir uma memória coletiva que lhes faça sentido no presente e que lhes possa servir de orientação futura (HERVIEU-LÉGER, 1998, p. 25; 1999, p. 62-63).

No entanto, seguindo o argumento, não existe sociedade humana sem um mínimo de memória que permita a produção de um sentido de existência cole-

\footnotetext{
18 Esse argumento é similar ao axioma das tradições culturais de Norris e Inglehart (2004, p. 17), na medida em que afirma que já não são as instituições religiosas a transmitir, exclusivamente, os valores sociais. Atualmente, essa missão é desempenhada pelo sistema de ensino ou pelos media que moldam, em cada país, a cultura e as tradições das diferentes comunidades nacionais.
} 
tiva (HERVIEU-LÉGER, 1998, p. 26). Precisamente para evitarem situações de vazio simbólico, criadas pela perda de unidade e profundidade da memória coletiva, os indivíduos juntam-se em pequenos, múltiplos e fragmentados grupos de memória religiosa (HERVIEU-LÉGER, 1998, p. 27-29). Algo semelhante àquilo que Luckmann (1990) definira como comunidades de transcendências pequenas que, apesar da sua dimensão, continuam a poder aproveitar o capital de memória existente em si e nas sociedades modernas e construir gradual e coletivamente uma estrutura simbólica das relações sociais (HERVIEU-LÉGER, 1999, p. 53-54; 2000, p. 173).

Para Hervieu-Léger (1998, p. 27; 1999, p. 180-186), isto apresenta um paradoxo: no contexto de uma sociedade secularizada e com dinâmicas sociais e culturais rápidas, surgem grupos religiosos pequenos, de adesão voluntária, forjados pelos interesses dos próprios indivíduos. ${ }^{19} \mathrm{Ou}$ seja, assistimos a processos de dissolução da autoridade das tradições religiosas institucionalizadas e de atomização dos indivíduos que promovem, paradoxalmente, uma forma de religião pós-tradicional - mutável e sujeita a revisão e altamente subjetivizada e emocional -, caracterizada pela formação de comunidades emocionais voluntárias ligadas por meio de uma memória religiosa dispersa. ${ }^{20}$

Essa tendência revela uma reversão no processo de construção de identidades religiosas (HERVIEU-LÉGER, 1998, p. 27). Por um lado, em sociedades tradicionais, o universo simbólico-religioso e a memória coletiva geral eram oferecidos e eram visíveis nas suas estruturas, linguagem ou práticas quotidianas. Por outro lado, no caso de sociedades diferenciadas, onde a memória perdeu a maioria do seu papel organizativo, a memória coletiva tornou-se objeto de uma constante reavaliação (HERVIEU-LÉGER, 1999, p. 89). Por oposição ao desaparecimento de uma memória religiosa vivida nas ações do quotidiano, encontramos o desenvolvimento de uma religiosidade festiva que se manifesta por meio do extraordinário e do excepcional. Surge uma nova temporalidade religiosa, de momentos de pico, que tende a substituir a temporalidade cíclica da vida litúrgica, e uma nova geografia

19 Hervieu-Léger (1999, p. 115-116; 2000, p. 163-165) utiliza a metáfora do supermercado religioso ou do mercado simbólico, onde o indivíduo circula e satisfaz as suas necessidades em função das suas carências e preferências. Isso assemelha-se à ideia de nascimento da cultura de consumo já citada em Luckmann (1967), Davie (2006) e Roof (2001).

20 Isso sucede, segundo Hervieu-Léger (2001, p. 166), como reflexo dos laços sociais criados pela, supracitada, religiosidade nova era. Essencialmente, por conta dos vínculos estabelecidos entre os indivíduos nas novas cooperativas de recursos espirituais (livrarias ou estabelecimentos educacionais) e das suas novas lógicas de autovalidação das crenças, centradas nas verdades subjetivas. 
religiosa, situada em grandes lugares sagrados (por exemplo, santuários). A religião abandona a memória viva de uma comunidade local e passa a ser encontrada nesses novos tempos e locais de memória, caracterizados por "celebrações efémeras e rituais esporádicos de sociedades sem rituais” (HERVIEU-LÉGER, 1998, p. 29).

\section{Considerações finais}

Nesta etapa derradeira do nosso trabalho, não pretendemos redizer nem reexaminar os argumentos das teorias em análise. A nossa intenção é outra. De modo a aumentar os ganhos epistemológicos, consideramos ser mais útil sistematizar as suas principais diferenças.

Assim sendo, organizamos uma tabela de análise com a comparação esquemática entre alguns dos principais pontos de discussão entre as duas teorias.

Tabela 1: Comparação esquemática entre as teorias da secularização e individualização

\begin{tabular}{|c|c|c|}
\hline & Secularização & Individualização \\
\hline Ponto de partida sociológico & Estrutura & Agência \\
\hline $\begin{array}{l}\text { Religião como variável em- } \\
\text { pírica }\end{array}$ & Dependente & Independente \\
\hline $\begin{array}{l}\text { Explicação mobilização re- } \\
\text { ligiosa }\end{array}$ & Macrossociológica & Microssociológica \\
\hline $\begin{array}{l}\text { Localização social da reli- } \\
\text { gião }\end{array}$ & Pública, mas privatizando-se & Subjetividade individual \\
\hline Modelo de poder & Poder estruturado & Escolhas individuais \\
\hline Hipótese principal & $\begin{array}{l}\text { Religião perde relevância } \\
\text { social e a sua posição predo- } \\
\text { minante no que concerne à } \\
\text { interpretação do mundo }\end{array}$ & $\begin{array}{l}\text { Religião institucionalizada } \\
\text { perde relevância social, } \\
\text { mas a religiosidade indi- } \\
\text { vidual mantém relevância } \\
\text { estável }\end{array}$ \\
\hline Paradigma histórico & $\begin{array}{l}\text { Catolicismo medieval (Euro- } \\
\text { pa, séculos V e XV) }\end{array}$ & $\begin{array}{l}\text { Religiosidades nova era (a } \\
\text { partir da década de } 1970) \\
\end{array}$ \\
\hline Narrativa principal & Secularização linear & $\begin{array}{l}\text { Desprivatização da } \\
\text { religião }\end{array}$ \\
\hline Processo principal & Diferenciação & Proteanismo \\
\hline $\begin{array}{l}\text { Relação modernização-reli- } \\
\text { gião e efeitos na religião }\end{array}$ & $\begin{array}{c}\text { Problemática e, tendencial- } \\
\text { mente, negativa }\end{array}$ & $\begin{array}{c}\text { Compatível e, tendencial- } \\
\text { mente, positiva }\end{array}$ \\
\hline
\end{tabular}


A observação da Tabela 1 nos ajuda a compreender melhor alguns dos seus pressupostos fundamentais. De um lado, as teorias da secularização, seguindo a narrativa histórica da Idade de Ouro da religiosidade medieval cristã, dizem que existe um contraste fundamental entre religião e modernização que conduz, inevitavelmente, a um declínio na relevância social da primeira. Ela perde a sua centralidade social no que diz respeito à interpretação do mundo. As teorias da individualização, de outro lado, também reconhecem o impacto da modernização na religião. Todavia, analisando correntes religiosas ou espirituais mais atuais (como as do tipo nova era), distinguem entre os seus efeitos nas dimensões macrossociológica (institucional) e microssociológica (individual), argumentando que o decréscimo da relevância da religião se dá apenas na primeira. A segunda dimensão mantém uma relevância constante, podendo até ter desenvolvimentos positivos, face aos avanços dos fenômenos da modernização; porém, os seus teóricos esperam que as suas formas e expressões estejam em permanente adaptação e transformação, variando consoante os diferentes contextos sociais e anseios individuais. Essa diferença entre ambas as teorias deve-se, entre outros aspetos, à arquitetura científica do seu conceito de religião. Enquanto nas teorias da secularização a religião é entendida como uma variável dependente, ou seja, como algo que os processos sociais modernos podem afetar de maneira adversa e cuja relevância social e pessoal varia, tendencialmente de forma negativa, ao longo do tempo e do espaço; nas da individualização ela passa a ser encarada como uma variável independente - uma força cultural e social moldável, mas inabalável, capaz de se organizar a si mesma, quer em pequenos grupos de memória religiosa quer, exclusivamente, na subjetividade de cada indivíduo.

Não obstante reconheçamos que ainda existe muito por fazer, relativamente ao estudo de um conceito essencialmente contestado como o de secularização; consideramos que a aplicação do método comparativo e a sistematização analítica beneficiam os cientistas sociais que se debruçam sobre assuntos religiosos. O confronto sistemático das teorias da secularização e da individualização não só nos ajudou a explorar padrões de similaridade e diferença; mas, sobretudo, a explicar, tão ostensivamente quanto possível, como é possível que dois modelos teóricos, com objetos de estudo análogos, possam ter conduzido à inferência de resultados tão diferentes quanto à (in)variação ou à (falta de) vitalidade religiosa nas sociedades hodiernas. 


\section{Referências}

BECK, U. Risk Society: Towards a New Modernity, 1. ed. Londres: SAGE Publications, 1992.

BECK, U. A God of One's Own: Religion's Capacity for Peace and Potential for Violence. Trad. Rodney Livingstone. Cambridge: Polity, 2010.

BECK, U.; BECK-GERNSHEIMM, E. Individualization: Institutionalized Individualism and Its Social and Political Consequences, v. 13. Londres: Sage Publications, 2002.

BELLAH, R. Religious Evolution. American Sociological Review, v. 29, n. 3, 1964, p. 358-374.

BELLAH, R. The Broken Covenant: American Civil Religion in Time of Trial. Nova Iorque: The Seabury Press, 1975.

BELLAH, R. et al. Habits of the Heart: Individualism and Commitment in American Life. Los Angeles: University of California Press, 1985.

BERGER, P. The Sacred Canopy: Elements of a Sociological Theory of Religion. Nova Iorque: Anchor Books, 1990 [1967].

BESECKE, K. Speaking of Meaning in Modernity: Reflexive Spirituality as a Cultural Resource. Sociology of Religion, v. 62, n. 3, 2001, p. 365-381.

BREMMER, J. Secularization: Notes toward a genealogy. In: VRIES, H. (Org.). Religion: Beyond a Concept. Nova Iorque: Fordham University Press, 2008.

BRUCE, S. God is Dead: Secularization in the West. Cornwall: Blackwell Publishing, 2002.

BRUCE, S. Secularization and the Impotence of Individualized Religion. The Hedgehog Review, v. 8, n. 1-2, 2006, p. 35-45.

BRUCE, S. Secularization: In Defence of an Unfashionable Theory. Oxford: Oxford University Press, 2011.

CASANOVA, J. Public Religions in the Modern World. Chicago: University of Chicago Press, 1994.

COLLIER, D. The comparative method. In: FINIFTER, A. W. (Org.). Political Science: The State of the Discipline II. Washington: American Political Science Association, 1993.

DAVIE, G. Religion in Britain Since 1945: Believing Without Belonging, 1. ed. Oxford: Wiley-Blackwell, 1994.

DAVIE, G. Europe the exceptional case. Parameters of faith in the modern world. Londres: Darton, Longman \& Todd, 2002.

DAVIE, G. Is Europe an Exceptional Case? The Hedgehog Review, v. 8, n. 1-2, 2006, p. 23-34. 
DAVIE, G. The Sociology of Religion. Londres: Sage Publications, 2007.

DAVIE, G. The Sociology of Religion: A Critical Agenda, 2. ed. Londres: SAGE Publications, 2013.

FULLER, R. C. Spiritual, But Not Religious: Understanding Unchurched America, 1. ed. Oxford: Oxford University Press, 2001.

GEERTZ, C. Thick description toward an interpretive theory of culture. In: The Interpretation of Cultures: Selected Essays. Nova Iorque: Basic Books, 1973.

GORSKI, P. Historicizing the Secularization Debate: Church, State, and Society in Late Medieval and Early Modern Europe, ca. 1300 to 1700. American Sociological Review, v. 65, n. 1, 2000, p. 138-167.

GORSKI, P. Historicizing the secularization debate: An agenda for research. In: DILLON, M. (Org.). Handbook of the Sociology of Religion. Cambridge: Cambridge University Press, 2003.

HADDEN, J. Towards desacralizing secularization theory. Social Forces, v. 65, n. 3, 1987, p. 587-611.

HELLEMANS, S. Secularization in a religiogeneous modernity. In: LAERMAN R. et al. (Orgs.). Secularization and Social Integration: Papers in Honor of Karel Dobbelaere. Col. Sociology Today, v. 4. Lovaina: Leuven University Press, 1998.

HERVIEU-LÉGER, D. Secularization and religious modernity in Western Europe. In: SHUPE, Anson D.; MISZTAL, Bronislaw (Orgs.). Religion, Mobilization, and Social Action. Westport: Greenwood Publishing Group, 1998.

HERVIEU-LÉGER, D. La religion en mouvement: le pèlerin et le converti. Paris: Flammarion, 1999.

HERVIEU-LÉGER, D. Religion as a Chain of Memory. Cambridge: Polity Press, 2000.

HERVIEU-LÉGER, D. Individualism, the validation of faith, and the social nature of religion in modernity. In: FENN, R. K. (Org.). The Blackwell Companion to Sociology of Religion. Trad. Michael Davis, 2001.

HOWARD, C. Introducing individualization. In: HOWARD, C. (Org.). Contested Individualization: Debates about Contemporary Personhood. Nova Iorque: Palgrave Macmillan, 2007.

KNOBLAUCH, H. Spirituality and Popular Religion in Europe. Social Compass, v. 55, n. 2, 2008, p. $140-153$.

LIFTON, R. J. The Protean Self: Human Resilience in an Age of Fragmentation. Chicago: University of Chicago Press, 1999. 
LUCKMANN, T. The Invisible Religion: The Problem of Religion in Modern Society. Nova Iorque: Macmillan, 1967.

LUCKMANN, T. Shrinking Transcendence, Expanding Religion? Sociological Analysis, v. 50, n. 2, 1990, p. 127-138.

LUCKMANN, T. The old and the new in religion. In: BOURDIEU, P.; COLEMAN, J. S. (Orgs.). Social theory for a changing society. Nova Iorque: Westview Press, 1991.

LUHMANN, N. Social Systems. Trad. J. Bednarz Jr. e D. Baecker. Stanford: Stanford University Press, 1995.

MARTIN, D. A General Theory of Secularization. Oxford: Blackwell, 1978.

NORRIS, P.; INGLEHART, R. Sacred and Secular: Religion and Politics Worldwide. Cambridge: Cambridge University Press, 2004.

PARSONS, T. Les systèmes des sociétés modernes. Paris: Dunod, 1973.

PARSONS, T. The Evolution of Societies. New Jersey: Prentice-Hall, 1977.

PICKEL, G. Secularization, Individualization or Market Approach? Results from the "Church and Religion in an Enlarged Europe" Project. In: WILDMANN, J. (Org.). Religions and Churches in a Common Europe. Bremen: Europaeischer Hochschulverlag \& Co., 2012.

PICKEL, G.; SAMMET, K. Introduction: Transformations of Religiosity in Central and Eastern Europe. Twenty years after the breakdown of communism. In: PICKEL, G.; SAMMET, K. (Orgs.). Transformations of Religiosity: Religion and Religiosity in Eastern Europe 19892010. Wiesbaden: Springer-Verlag, 2012.

POLLACK, D. Introduction: Religious change in modern societies - Perspectives offered by the sociology of religion. In: POLLACK, D.; OLSON, Daniel (Orgs.). The Role of Religion in Modern Societies. Londres: Routledge, 2011.

POLLACK, D.; PICKEL, G. Church-State relations and the vitality of religion in European comparison. In: PICKEL, G.; MÜLLER, O. (Orgs.). Church and Religion in Contemporary Europe. Results from Empirical and Comparative Research. Wiesbaden: Springer-Verlag, 2009.

ROBERTS, K.; YAMANE, D. Religion in Sociological Perspective, 5. ed. Los Angeles: Sage, 2012.

ROOF, W. C. Today's spiritual quests, 1997, p. 93-101. Disponível em http://www2.ptsem. edu/uploadedFiles/IYM/YCCL/Roof-Todays.pdf. Acesso em 7 out. 2016.

ROOF, W. C. Spiritual Marketplace: Baby Boomers and the Remaking of American Religion. Princeton: Princeton University Press, 2001. 
SMELSER, N. Comparative Methods in the Social Sciences. Col. Classics of Social Sciences. New Orleans: Quid Pro Books, 2013 [1976].

STARK, R. Secularization, R.I.P. Sociology of Religion, v. 60, n. 3, 1999, p. 249-273.

STOLZ, J. A Silent Battle. Theorizing the Effects of Competition between Churches and Secular Institutions. Review of Religious Research, v. 51, n. 3, 2010, p. 253-276.

TSCHANNEN, O. Les théories de la sécularisation. Genebra: Librairie Droz, 1992.

WILSON, B. Religion in Secular Society: A Sociological Comment. Harmondsworth: Penguin Books, 1969.

WILSON, B. Contemporary Transformation of Religion. Oxford: Oxford University Press, 1976.

WILSON, B. Religion in Sociological Perspective. Oxford: Oxford University Press, 1982.

Submetido em: 9-10-2016

Aceito em: 22-7-2017 